\title{
The Bank, the Bond and the Bail-Out: On the Legal Construction of Market Discipline in the Eurozone
}

\section{HARM SCHEPEL*}

We must not simply abandon interest rates as a disciplinary mechanism. Governments need the markets. Markets tell governments things that governments don't want to hear. And they force governments to do the right thing.

$$
\text { Wolfgang Schäuble }{ }^{1}
$$

\section{Introduction}

The power of market discipline to constrain spendthrift states is, by now, widely seen as an indispensable complement- or alternative- to the legal mechanisms in the Treaty and beyond to enforce the limits on Member States' debts and deficits in Economic and Monetary Union. ${ }^{2}$ Its legal anchoring is said to be in the 'no bail-out' clauses of Articles 123 and 125 TFEU, prohibiting monetary financing of national debt by the European Central Bank and national central banks, and the assumption of liability for the debts of any Member State by other Member States and the Union. In one of its least contested observations in Pringle, the Court of Justice of the European Union held that the purpose of these 'no bail-out' clauses is to ensure that Member States 'remain subject to the logic of the market when they enter into debt, since that ought to prompt them to maintain

\footnotetext{
Kent Law School and Brussels School of International Studies, University of Kent. Espace Rolin, Boulevard Louis Schmidt 2a, 1040 Brussels.

hjcs@kent.ac.uk.

1 Wolfgang Schäuble, A Comprehensive Strategy for the Stabilization of the Economic and Monetary Union, Speech at the Brussels Economic Forum, 18 May 2011. http://ec.europa.eu/economy_finance/bef2011/media/files/speech-brussels-economic-forumschauble.pdf

2 On the hardening of these legal constraints, see for example M. Adams, F. Fabbrini and P. Larouche (eds.) The Constitutionalization of European Budgetary Constraints (2014).
} 
budgetary discipline. ${ }^{3}$ Accordingly, the 'logic of the market' is the standard of legality of financial assistance to indebted Member States under EU Law and, ultimately, the legal justification for strict conditionality and the imposition of austerity. This logic of the market, though, is something different from actual market behavior. This was necessarily so in the two grand Euro-crisis judgments of the Court. The European Stability Mechanism gives assistance only to Member States who have lost access to markets in the first place, leaving the Court in Pringle with the task of deciding whether the conditions the ESM imposed on beneficiaries prompted budgetary discipline according to the logic of the market. The Outright Monetary Transactions of the ECB were explicitly meant to correct the 'excessive' interest rates charged of indebted Member States in the sovereign debt market, leaving the Court in Gauweiler with the arduous task of deciding whether the market behaved according to the logic of the market. ${ }^{4}$ The logic of the market also has little bearing on the history of the cost of debt in the Eurozone; the markets have gotten it clearly 'wrong' time and again, ${ }^{5}$ which makes the proposition that they can 'force governments to do the right thing' tenuous at best.

This paper is not concerned with the implications of the judgments in Pringle and Gauweiler on the constitutional structure and legal integrity of the European Union. ${ }^{6}$ It focuses,

${ }^{3}$ Case C-370/12 Thomas Pringle EU:C:2012:756, para 135. Compare M. Herdegen, 'Price Stability and Budgetary Restraints in the Economic and Monetary Union: The Law as Guardian of Economic Wisdom', Common Market L Rev (1998) 35: 9-32, 22 ('[T] he no bail-out provision of the EC Treaty cannot sweep away the fact that the euro area will constitute a solidarity compact, the members of which are under a de facto obligation to rescue defaulting members.')

${ }^{4}$ Case C-62/14 Peter Gauweiler EU:C:2015:400.

5 'The story of the Eurozone is also a story of systematic mispricing of the sovereign debt.' P. de Grauw and Y. Ji, 'Mispricing of Sovereign Risk and Macroeconomic Stability in the Eurozone,' J Common Market Studies (2012) 50 (6), 866, at 879.

${ }^{6}$ See for example M. Dawson and F. de Witte, 'Constitutional Balance in the EU after the Eurocrisis', Modern L Rev (2013) 76: 87-844; E. Chiti and P. Teixeira, 'The constitutional implications of the European response to the financial and public debt crisis', Common Market L Rev (2013) 50: 683-708; K. Tuori and K. Tuori, The Eurozone Crisis: A Constitutional Analysis (2015); B. de Witte, 'Euro crisis responses and the EU legal order: increased institutional variation or constitutional mutation?', European Constitutional L Rev (11): 434-457; M. Ioannidis, 'Europe's 
instead, on the way the Court constructs 'market discipline' in its very absence as a legal requirement. It is a case of obscene politics masquerading as bad economics making for terrible law, rendering any financial assistance in the eurozone both as ineffective and as painful as possible.

\section{The Market in Sovereign Debt in Euroland, Part I}

The logic of the market in sovereign debt is cruel and clear. The worse a State's economic policy, the higher the debt, and the greater the risk of default. The higher that risk, the costlier borrowing becomes, and the more expensive the debt. The only way for States to get out of this vicious cycle is to pursue 'sound' budgetary policies, lower the debt, and be rewarded with lower interest rates. For this virtuous mechanism of market discipline to work, it is vital that government debt is priced 'correctly,' which necessitates markets processing information about 'market fundamentals' to estimate credit risk. The importance of the 'no bail-out' clauses lies there: if the market expects States to be bailed out in case of trouble, they will price government debt accordingly and create 'moral' hazard for debtors: borrowing will be cheap, and governments will pile up debt rather than making the hard and politically unpopular choices required under 'sound' budgetary policy. In sum: disaster can only be avoided if disaster is a credible prospect. This price formation takes place on secondary markets: bonds from sovereigns considered under risk will get sold at lower prices than their nominal value. Since the interest on these cut-price bonds remains the same, the return-on-investment, the yield, goes up. To be able to attract investors for new bonds, States will naturally have to offer interest rates that match the yield. Table 1 plots

New Transformations: How the EU economic constitution changed during the Eurozone crisis,' Common Market L Rev (2016) 53: 1237-1282, and especially A.J. Menéndez, "The Crisis of Law and the European crises: From the Social and Democratic Rechtsstaat to the consolidating state of (pseudo)technocratic governance', this issue. 
the debt-to-GDP ratios of Germany and the PIIGS in relation to long-term-yields on their sovereign bonds in the years leading up to the introduction of the Euro and the 'good years' thereafter until 2007.

Table 1 here $^{7}$

For all the crudeness of the measures, it is obvious that the table shows exactly the opposite of what the market was supposed to do. Convergence of yields started before the introduction of the Euro, and by 2002 the spread of yields between Member States with vastly divergent debt burdens steadied on scant decimals of percentage points. Greek and Italian debt ratios remained perilously close to double the $60 \%$ prescribed by EMU, and yet the cost of their debt was nearly identical to that of Germany. Spanish and Irish debt went down significantly and significantly below German debt levels, and yet the cost of their debt was nearly identical to that of Germany. Whatever else the markets may have been punishing or rewarding, 'budgetary discipline' or lack thereof was clearly not on their minds. ${ }^{8}$

If the markets were creating moral hazard among debtor States, one of the causes was clearly the moral hazard created among creditors by European banking regulation. Banks operate under capital requirements limiting their leverage and exposure. The capital ratio is expressed as a percentage of the regulatory capital banks are to hold in relation to their lending and investment. That lending and investment, in turn, is 'risk-weighted,' forcing banks to have higher capital ratios for 'riskier' assets. Exposure limits seek to diversify risk by limiting the proportion of lending and investment to particular assets. These regulatory requirements have proven spectacularly ineffective, of course, with banks and other financial institutions finding ways above, beyond and around almost any regulatory limit imposed on them. ${ }^{9}$ For sovereign debt, however, there has never been any need at all to be

\footnotetext{
7 Source: Ameco.

8 But see Ch. Rommerskirchen, 'Debt and Punishment: Market Discipline in the Eurozone', New Political Economy (2015), 20: 752-782 (finding that membership of EMU reduces market punishment but increases policymakers' responsiveness).

9 See, for example, A. Admati and M. Hellweg, The Bankers' New Clothes- What's wrong with banking and what to do about it (2013).
} 
creative. Exposure to Member States' central governments is assigned a risk weight of $0 \%{ }^{10}$ Limits to exposure to sovereign debt are non-existent. Banks can pile up as much sovereign debt as they please.

Regulating risk away from sovereign debt seems a strange way to ensure that markets correctly price risk. And yet, perversely, the rationale behind the regulatory treatment of sovereign debt seems to have been to render markets more, not less, attuned to the risk of insolvency of Member States. One of the factors polluting price formation, so the theory goes, is 'liquidity risk': if investors fear that they will not be able to re-sell their bonds, their appetite for sovereign bonds will go down and the cost of debt will go up. The zero-risk weighting, by increasing demand for sovereign debt, will increase liquidity and hence 'free' markets to price risk 'correctly'. With a bit of effort, one could still see 'the logic': that demand for the asset class of sovereign debt will go up and the return on the asset class of sovereign debt will go down doesn't necessarily mean that financial institutions will not be able to distinguish between the sovereign debt of Germany and that of, say, Greece or Italy. Except that banks will want to make some money even on zero-risk-weighted assets. As long as there is some spread left between Italian and Greek bonds and German bonds, periphery debt will be the more rewarding. As the spread decreases, banks will need more and more of periphery debt for it still to be worthwhile, thus increasing demand further, and decreasing the yield further still until the spread is all but gone. At this point banks find themselves with enormous leveraged exposure to sovereigns whose budgetary policies are blissfully unaffected by any market discipline. It is here that the final perversity kicks in: in what Mark Blyth has called 'the mother of all hazard trades', banks decided to buy up still more periphery debt at still higher leverage (and at still lower yields) until they became so big as to virtually ensure that they would be 'too big to fail' and be bailed out in case their

10 Article 114 (4), Regulation 575/2013 on prudential requirements for credit institutions and investment firms, (2013) OJ L 321/6. Frankfurt has had enough. See J. Weidmann, 'Stop encouraging banks to load up on state debt', Financial Times 1 October 2013; C. Buch, M. Koetter and J. Ohls, 'Banks and sovereign risk: a granular view', Deutsche Bundesbank Discussion Paper 29/2013, and Deutsche Bundesbank, Reducing the privileged regulatory treatment of sovereign exposures, Annual Report 2014. See also European Systemic Risk Board, ESRB Report on the regulatory treatment of sovereign exposures (2015). 
sovereign assets would lose value and the house of cards would come tumbling down. ${ }^{11} \mathrm{~A}$ few odd rogue banks that are 'too big to fail' can, of course, be bailed out without getting States into unsurmountable trouble. An entire banking system that is collectively 'too big to fail' will, however, become 'too big to bail. ${ }^{12}$ And so the banking crisis transforms into a sovereign debt crisis. ${ }^{13}$

\section{Pringle and what the market would say}

In an attempt to address the ensuing crisis, the European Stability Mechanism was set up to provide financial assistance to Member States in severe difficulties. Not unreasonably, the matter of the compatibility of financial assistance with the 'no bail-out clause' was raised widely, and came before the Court of Justice in Pringle. ${ }^{14}$ The Court derived from Articles

11 M. Blyth, Austerity- the history of a dangerous idea (2013), at 81. See also, more formally, V. Acharya and S. Steffen, 'The "greatest" carry trade ever? Understanding Eurozone bank risks', $J$ of Financial Economics (2015) 115: 215-236. The plot thickens when one factors in the repo market, or the way banks use sovereign debt as collateral in borrowing cash. See D. Gabor and C. Ban, 'Banking on Bonds: The New Links Between States and Markets', J of Common Market Studies (2016) 54 (3): 617-635.

${ }^{12}$ See for example A. Mody and D. Sandri, "The Eurozone crisis: how banks and sovereigns came to be joined by at the hip', Economic Policy (2012) 27 (70): 199-230, and V. Acharya, I. Drechsler and P. Schnabl, 'A Pyrrhic Victory? Bank Bailouts and Sovereign Credit Risk', J of Finance (2014) 69 (6): 2689-2739.

${ }^{13}$ Cumulated support measures to banks in the Eurozone as a whole amounted to 8\% of GDP. See ECB, The fiscal impact of financial sector support during the crisis, ECB Economic Bulletin, Issue 6/2015. https://www.ecb.europa.eu/pub/pdf/other/eb201506 article02.en.pdf. This is a common pattern in history. Even without large scale bailouts, Reinhart and Rogoff estimate that government debts 'typically' rise about $86 \%$ in the three years following a systemic financial crisis, largely owing to collapsing revenues. C. Reinhart and K. Rogoff, 'From Financial Crash to Debt Crisis', American Economic Rev (2011) 101 (5): 1676-1706.

${ }^{14}$ See generally for example T. Beukers and B. de Witte, "The Court of Justice approves the creation of the European Stability Mechanism outside the EU legal order: Pringle', Common Market Law Rev (2013) 50: 805-848, P. Craig, 'Pringle: Legal Reasoning, Text, Purpose and 
122 and 123 TFEU that the purpose of Article 125 TFEU cannot be to prohibit all financial assistance by one Member State to another. ${ }^{15}$ To divine the precise meaning of the prohibition, then, the Court decided to look at the purpose of the provision, which it formulated as follows:

The prohibition laid down in Article 125 TFEU ensures that the Member States remain subject to the logic of the market when they enter into debt, since that ought to prompt them to maintain budgetary discipline. Compliance with such discipline contributes at Union level to the attainment of a higher objective, namely maintaining the financial stability of the monetary union. ${ }^{16}$

From this, the Court held it to follow logically that the reach of the 'no bail-out' clause is limited to forms of financial assistance that 'diminish' the 'incentive' for Member States to pursue sound budgetary policies. ${ }^{17}$ From that, in turn, it follows for the Court that bail-outs are perfectly compatible with Article 125 TFEU as long as the beneficiary Member State 'remains responsible for its commitments to its creditors' and if they are subject to 'strict conditions. $^{18}$

The aim of Article 125 TFEU is thus to ensure the proper working of the market in sovereign debt. Now, as such, the link between the 'no bail-out' clause and correct price formation on sovereign bond markets is fairly straightforward: unless default is a credible prospect, the risk of default is never to going to be priced properly, and the market will not be able to provide the correct incentives to indebted States. In other words, for the Iogic of the market' to exert its magic, it is vital that creditors live in fear of losing their money, ${ }^{19}$ and

Teleology', Maastricht J of European and Comparative L (2013) 20: 3-11, and G. Beck, 'The Court of Justice, legal reasoning, and the Pringle case- law as the continuation of politics by other means', European L Rev (2014) 39: 234-250.

15 Pringle, para 132.

16 Ibid., para 135.

17 Ibid., para 136.

18 Ibid., para 137.

${ }^{19}$ See Q. Peel and R. Atkins, 'Financial Markets "do not understand the euro"', Interview with Wolfgang Schäuble, Financial Times, 6 December 2010 ('Mr. Schäuble warned that if private 
that debtors live in fear of full-blown disaster. If we take the Court seriously, then, we are to believe that a credible threat of financial instability in the monetary union contributes to the 'higher objective' of financial stability in the monetary union. For the compatibility of the ESM with Article 125 TFEU, the disastrous implication of the 'logic of the market' is that a bail-out is only lawful if everyone behaves as if there were no bail-out. That, in turn, leads to an obligation on the ESM to be as ineffective as possible, and to inflict as much pain and misery on the populations of debtor states as feasible.

The distributional consequences of the requirement that any financial assistance may not intervene in the relationship between the debtor state and its creditors are clear enough: by granting loans to debtor states with which these are then to service their debt to private creditors in full, taxpayers from creditor states are effectively transferring money to (their) banks. This may not be fair, but it could still conceivably be useful to citizens from debtor states if the loans would be plentiful enough to guarantee creditors payment: in that case, risk premiums would disappear, debt would become cheaper, and the debtor state could perhaps start thinking about allocating some if its very scarce resources to purposes other than paying off banks. But Article 125 TFEU will not actually allow loans to be that useful. Advocate General Kokott explains:

Direct support of the creditors is prohibited, while indirect support, which arises as a result of the support to the debtor Member State, is not prohibited. The creditors of a Member State will therefore as a rule benefit from support given to that Member State. There remains however for the potential creditors of a Member State an additional uncertainty as to whether possible financial assistance to a Member State may actually lead to the satisfaction of their demands. To that extent, the voluntary support of a Member State need not inevitably be accompanied by either a complete or even partial satisfaction of the Member State's creditors. That uncertainty is intended to promote the objective that Member States have differentiated interest rates on the capital markets. ${ }^{20}$

bondholders did not bear some risk, as well as the reward, of investing, it could destroy the legitimacy of the market economy and even "our political order".')

20 Pringle, View of AG Kokott, para 148. Emphasis added. 
It is an astonishing piece of logic that will make the legality of a financial assistance program conditional upon it being useless.

The Court itself is much less candid, or just less clear. For loans and purchases of bonds on primary markets, the requirement poses no problem: here, the beneficiary Member State contracts new debt, and remains responsible to its original creditors for existing debt. ${ }^{21}$ Article 18 of the ESM Treaty, however, also makes provision for the purchase of sovereign bonds on secondary markets. If it does not exactly or necessarily constitute 'support', such a transaction surely does at least 'benefit' the original bondholder: after all, if she wouldn't see any benefit in the sale, she wouldn't be selling. In addressing this, the Court pens one of the more mysterious passages in Pringle:

Next, as regards the purchase on the secondary market of bonds issued by an ESM Member, it is clear that, in such a situation, the issuing Member State remains solely answerable to repay the debts in question. The fact that the ESM as the purchaser on that market of bonds issued by an ESM Member pays a price to the holder of those bonds, who is the creditor of the issuing ESM Member, does not mean that the ESM becomes responsible for the debt of that ESM Member to that creditor. That price may be significantly different from the value of the claims contained in those bonds, since the price depends on the rules of supply and demand on the secondary market of bonds issued by the ESM Member concerned. ${ }^{22}$

The Court obviously thinks it is important that the price of the bonds be determined under normal market conditions, but it is a little cryptic as to why this is. Thankfully, the Advocate General provides some help in the exegesis:

Although in the event of such a purchase of bonds the funds of the ESM flow directly to the creditor, in my opinion the prohibition on directly benefiting creditors continues to be observed if the bonds are acquired on normal market terms. The reason is that, in that case, the previous bondholder obtains his money as he would from any ordinary third party and does not derive any specific advantage from the

\footnotetext{
21 Pringle, paras 139-140.

22 Ibid., para 141. Emphasis added.
} 
capacity of another Member State. When an ordinary purchase is made on the securities market the creditor would also be unaware that the purchaser of the bond is a Member State. Such a bond purchase is therefore not designed to build up the confidence of potential creditors of a Member State in the capacity of another Member State.

It is not evident that the deployment of financial assistance instruments under Article 18 of the ESM Treaty would necessarily deviate from the circumstances described. The purchase of bonds by the ESM in accordance with that provision therefore is not a priori necessarily incompatible with Article 125 TFEU; rather there exists in any event the possibility of effecting those purchases in a way that complies with its provisions. ${ }^{23}$

If this is really the reasoning behind the Court's reference to the laws of supply and demand, it is easy to see why it wouldn't necessarily want to spell it out more clearly. By the time the ESM would be triggered, the threat of insolvency of a State in need of help will be such that bondholders are selling off to save what they can. The price will be down, and the yield will be up. This is vulture fund territory: at a few cents to the Euro, investment in junk bonds is very risky, but potentially very profitable if the State will be able and willing (or forced) to pay the full nominal value of the claim. According to the Court's logic, purchases of bonds in such circumstances are perfectly fine under Article 125 TFEU: the debtor State will still have to repay its debt, and the previous bondholders do not derive any benefit up and above 'normal' market prices. As long as the ESM conducts these purchases by stealth and without upsetting the market, the transactions may conceivably be considered compatible with the no bail-out clause.

Assuming that the ESM wasn't set up as a vulture fund, however, it is hard to see what the benefit would be to anyone for it to act the way the Court instructs it to conduct its business: a financial assistance program that is not allowed to make either creditors or debtors better off is not likely to be of much use to anyone. The very purpose of purchasing bonds on secondary markets is to upset 'normal market conditions': restore confidence,

23 Pringle, View of AG Kokott, paras 158-159. 
increase demand, get the price up, get the yield down, and get the cost of debt down. And as Mario Draghi would show to dramatic effect in the OMT saga, this is best done not in secret but by waving a bazooka around.

If the 'logic of the market' makes the ESM as ineffective as feasible, it also makes its assistance as painful as possible on the recipient state and its population. It may be worth recalling how the Court gets from a 'no bail-out clause' to a requirement of strict conditionality- and thereby freezes the enactment of austerity measures into a legal obligation for states in financial distress. On the Court's construction, Article 125 TFEU doesn't actually prohibit financial assistance, it exists only to preserve 'the logic of the market' in sovereign debt. Article 125 TFEU doesn't actually impose budget discipline; the impetus to pursue sound policies is merely a contingent by-product of 'the logic of the market.' That logic, in turn, depends on price formation not being polluted by expectations of bail-outs. Once a facility is in place to in effect 'bail out' debtor states, that logic is obviously out of the window, and the markets are not going to exert any disciplinary power. The Court's fundamental move, then, is to sanction the substitution of political decisions on austerity for the 'logic of the market' and to force assisted states to behave as if they were headed for insolvency. The purpose of this exercise is not to work out the most sensible path to the restoration of growth and financial health for the assisted state but to restore some semblance of 'the logic of the market' to the sovereign debt markets of other Member States: if not by the discipline of unpolluted markets themselves, States will have to be deterred from pursuing unsound budgetary policies by the prospect of having to live through the same amount of pain and misery inflicted on states assisted by the ESM. The measure of punishment inflicted, then, is not a matter of market forces but of a political decision whose legality is bounded by theoretically contested and empirically unfounded assumptions about the 'the logic of the market' and about the sacrifices the markets would have demanded of debtor states had they not been unable to meet the demands of the markets in the first place. ${ }^{24}$ All of this comes totally unhinged when the Court will have to admit, as a matter of EU Law, that the markets get it 'wrong.'

\footnotetext{
${ }^{24}$ As Michelle Everson puts it: 'the most disturbing feature of crisis-busting jurisprudence is its legal ossification of a violently disputed economic theory of market-disciplined structural
} 


\section{The Market in Sovereign Debt in Euroland, Part II}

After the collapse of Lehman Brothers, sovereign debt markets in the Eurozone woke up from their slumber and for the fateful years between 2008 and 2012 seemed to be doing what the 'logic of the market' would predict. As Greek sovereign debt spiraled out of control, so did the yield on Greek bonds. Rapidly rising Portuguese debt was duly punished with increased borrowing costs. As Spain and Ireland recapitalized their banks and turned a financial crisis into a sovereign debt crisis, they too were hit hard. ${ }^{25}$ And even Italy- which largely remained as sluggish and indebted as it had been for a long time- came in for harsh treatment. As Table 2 shows, whatever the markets woke up from or to, the reaction was abrupt and violent. The disciplinary power of the market was finally unleashed.

Table 2 here h $^{26}$

renewal at a time of radicalized protest against austerity at national level.' M. Everson, 'A Technocracy of Governing: Power without the State; Power without the Market', in C. Joerges \& C. Glinski (eds.), The European Crisis and the Transformation of Transnational Governance (2014), 227, at 229. See also C. Kaupa, 'Has (downturn-)austerity really been "constitutionalized" in Europe? On the ideological dimension of such claim', in this issue.

25 There are, of course, enormous differences between banking systems in the various Member States, which go a long away in explaining the different paths towards sovereign debt crises (or not). See for example I. Hardie and D. Howarth, 'Die Krise but not La Crise? The Financial Crisis and the Transformation of German and French Banking Systems', J of Common Market Studies (2009), 47 (5): 1017-1039; I. Hardie and D. Howarth (eds.), Market-Based Banking and the International Financial Crisis (2013), and L. Quaglia and S. Royo, 'Banks and the political economy of the sovereign debt crisis in Italy and Spain', Rev of International Political Economy (2015) 22 (3): 485-507. The bigger the banking sector, the greater the effect on sovereign bond yields. S. Gerlach, A. Schulz and G. Wolff, 'Banking and sovereign risk in the Euro area', (2010) Deutsche Bundesbank Discussion Paper 09/2010. The bigger the bail-out, the greater the effect on sovereign bond yields. See M. Fratzscher and M. Rieth, 'Monetary policy, bank bailouts and the sovereign-bank risk nexus in the Euro area', (2015) CEPR Discussion paper 10370. ${ }^{26}$ Source: Ameco 
With the power of financial markets acutely felt, it became an article of faith that discrimination between member States was a good thing, and that the spread was a vital mechanism to have spendthrift states live up their responsibility and engage in the austerity policies of 'adjustment' and 'consolidation.' The Bundesbank rejoiced: 'market discipline- if actually exercised by market actors- offers a decisive incentive to guarantee sustainable long-term finances in the euro area. ${ }^{27}$

The moral, political and macroeconomic argument was won so decisively that the only space for viable contestation of austerity politics seemed to become econometrics. Not the power of financial markets per se was questioned, but their wisdom: what if they got it 'wrong'? An enormous literature spawned fairly soon from central banks and think tanks on the question of whether the markets were 'right', or more modestly, whether the 'correction' or 'revaluation' could plausibly be explained by 'market fundamentals' ${ }^{28}$ or rather at least partly also by panic and fear. ${ }^{29}$ A lot hinged on the matter: after all, 'if markets can stay irrational longer than a country can stay insolvent, their disciplinary power is considerably weakened. ${ }^{30}$ Dominant theory for quite some time held on to the central

27 Deutsche Bundesbank, Monthly Report, June 2011, at 44. Emphasis added.

28 The econometric models are complex, largely because of the need to avoid the almost inevitable endogeneity of nearly every conceivable set of correlating variables. See for example M.-G. Attinasi, C. Checherita and Ch. Nickel, 'What explains the surge in Euro area sovereign spreads during the financial crisis of 2007-2009?', (2009) ECB Working Papers 1131; S. Barrios, P. Iversen, M. Lewandowska and R. Setzer, 'Determinants of intra-euro area government bond spreads during the financial crisis', (2009) European Commission Economic Papers 388; M. Arghyrou and A. Kontonikas, 'The EMU sovereign-debt crisis: Fundamentals, expectations and contagion', J of International Financial Markets, Institutions and Money (2012) 22 (4): 658-677; J. Beirne and M. Fratzscher, 'The pricing of sovereign risk and contagion during the European sovereign debt crisis', (2013) ECB Working Papers 1625, and C. Chiarella et al., 'Fear of Fundamentals? Heterogenous beliefs in the European sovereign CDS market', $J$ of Empirical Finance (2015) 32: 19-34.

${ }^{29}$ A thesis brought to prominence by Paul de Grauwe. See for example P. de Grauwe and Y. Ji, 'Self-fulfilling Crises in the Eurozone: An Empirical Test', J of International Money and Finance (2013) 34: 15-36.

${ }^{30} \mathrm{C}$. Favero and A. Missale, 'Sovereign spreads in the eurozone: which prospects for a Eurobond?', Economic Policy (2012) 27: 231-273, at 267. 
role of country-specific weak fundamentals, and of increased skepticism of peripheral states' solvency- rather than contagious fears of a contagious break-up of the Eurozone. The Bundesbank at one point even suggested that the financial markets were sophisticated enough to price sovereign bonds according to the now infamous thesis of the $90 \%$ debt-toGDP 'cliff' above which growth was nigh impossible: ${ }^{31}$

The at times abrupt and massive revaluations can also be explained by the nonlinear relationship between the credit risk and the aforementioned fundamentals. ..There could be a type of threshold value with regard to fundamentals such as the debt ratio where - once surpassed - the markets are especially critical of any further increase. $^{32}$

The debate settled when the European Central Bank espoused the theory of a "bad equilibrium'- 'namely an equilibrium where you have self-fulfilling expectations that feed upon themselves and generate very adverse scenarios'- and Mario Draghi announced the OMT programme in September 2012 with the assurance to do 'whatever it takes' to reverse these expectations. ${ }^{33}$ As can be gleaned readily from Table 2, it worked rather well, and spreads were brought down despite periphery debt levels rising unperturbedly. So much for 'fundamentals. ${ }^{34}$ Yet, spreads remained decidedly higher than they had been before the crisis, leading to contentment in Frankfurt. In 2014, the Bundesbank reiterated its hardwiring of the EMU rulebook, proclaiming that spreads are not 'proof of a lack of

${ }^{31}$ C. Reinhart and K. Rogoff, 'Growth in a Time of Debt', American Economic Rev (2010) 100 (2): 573-578, notoriously undermined by T. Herndon, M. Ash and R. Pollin, 'Does high public debt consistently stifle economic growth? A critique of Reinhart and Rogoff', Cambridge J of Economics (2014) 38 (2): 257-279, and perhaps even more painfully by A. Pescatori, D. Sandri and J. Simon, 'Debt and growth: is there a magic threshold?', (2014) IMF Working Paper 14/34.

32 Deutsche Bundesbank, Monthly Report, June 2011, at 40-41.

${ }^{33} \mathrm{ECB}$, Introductory statement to the press conference (with Q\&A), 6 September 2012. http://www.ecb.europa.eu/press/pressconf/2012/html/is120906.en.html

${ }^{34}$ See for example P. de Grauwe and Y. Ji, 'Disappearing government bond spreads in the Eurozone: Back to normal?', CEPS Working Document 396 (2014), and M. Chang and P. Leblond, 'All In: Market expectations of Eurozone integrity in the sovereign debt crisis', Rev of International Political Economy (2015) 22 (3): 626-655. 
integration but represent an acceptable, if not to say highly desirable state of affairs which re- affirms the central role played by individual national responsibility within the euro area's regulatory framework.' 35

The debate about the markets' rationality played out differently in different policy contexts. Fears of 'moral hazard' were enough to stifle any serious discussion about the mutualization of debt through the issuance of Eurobonds. ${ }^{36}$ When first launched in the early days of the Euro, the idea was driven by worries about market fragmentation and lack of liquidity. ${ }^{37}$ Latter day iterations, on the other hand, bend over backwards to devise schemes, mechanisms and institutional arrangements to square the circle of mutualized debt, market discipline and individual responsibility. ${ }^{38}$ The Commission's own short-lived proposal of 'Stability bonds' is a good example of this. The proposal admits to 'possibly some degree of overshooting' on the part of the markets, but puts such faith in their disciplining power nonetheless that 'moral hazard' is to be avoided at all cost. ${ }^{39}$ And thus:

While yields of Stability Bonds would be market-based, funding costs might be differentiated across Member States depending on their fiscal positions or fiscal policies, or their market creditworthiness, as reflected by the risk-premium of national issuances over common issuances. This would provide an incentive for

35 Deutsche Bundesbank, Monthly Report, January 2014, 75.

${ }^{36}$ See M. Matthijs and K. McNamara, 'The Euro Crisis' Theory Effect: Northern Saints, Southern Sinners, and the Demise of the Eurobond', J of European Integration (2015) 37: 229-245.

37 Co-ordinated Public Debt Issuance in the Eurp Area- Report of the Giovannini Group, 8 November 2000. http://ec.europa.eu/economy finance/publications/publication6372 en.pdf. The Giovannini report, remarkably for post-crisis sensitivities, does not once mention the concepts of 'moral hazard' or even 'market discipline.'

38 See for example J. Muellbauer, 'Conditional Eurobonds and the Eurozone sovereign debt crisis', Oxford Rev of Economic Policy (2013) 29: 610-645; A. Hild, B. Herz and C. Bauer, 'Structured Eurobonds: Limiting Liability and Distributing Profits', J of Common Market Studies (2014) 52: 250-267, and R. Beetsma and K. Mavromatis, 'An analysis of eurobonds', J of International Money and Finance (2014) 45: 91-111.

${ }^{39}$ European Commission, Green paper on the feasibility of introducing Stability Bonds, COM (2011) 818 final, 7 
sound fiscal policies within the system and would mimic market discipline though in a smoother, more consistent fashion than markets. Such an incentive...could be further enhanced with 'punitive' rates in case of slippages from plans. ${ }^{40}$

With conditional financial assistance functioning as ersatz 'logic of the market', the problem over the last few years has been that financial markets have been defeating the economic theory behind austerity policies. ${ }^{41}$ Periphery countries are caught in a spiral of fiscal contraction, lower growth, higher debt, higher borrowing costs, more fiscal contraction, and so on. This may seem perfectly intuitive, but it was not supposed to be like this. Ecofin ministers, the European Commission, and the ECB have all been under the spell of the theory of 'expansionary fiscal consolidation' according to which serious spending cuts and deep structural reform may lead to short-term contractions, but will, after a year or so, actually return indebted countries to sustained growth. ${ }^{42}$ The blatant failure of austerity policies to deliver anything of the kind has led to a fierce debate between institutional creditors. For a chastened IMF, exaggerated growth forecasts and projections stem from a

40 Ibid., at 23.

${ }^{41}$ Markets do not welcome austerity. I. McMenamin, M. Breen and J. Muñoz-Portillo, 'Austerity and the credibility in the Eurozone', European Union Politics (2015) 16: 45-66.

42 The groundwork of the theory lies in F. Giavazzi and M. Pagano, 'Can Severe Fiscal Contractions be Expansionary? Tales of Two Small European Countries', in O. Blanchard and S. Fischer (eds.), NBER Macroeconomics Annual 1990, Volume 5 (1990), 75-122, and A. Alesina and S. Ardanga, 'Tales of Fiscal Adjustment', Economic Policy (1998) 13: 489-545. On how Alesina swayed the powers that be, see M. Blyth, Austerity- The History of a Dangerous Idea (2013), 169-177; S. Dellepiane-Avellaneda, 'The Political Power of Economic Ideas: The Case of “Expansionary Fiscal Contractions"', British J of Politics and International Relations (2015), 17: 319-418, and 0. Helgadóttir, 'The Bocconi boys go to Brussels: Italian economic ideas, professional networks and European austerity', J of European Public Policy (2016), 32: 392-409. Incredibly, the European Commission is still a fan. See European Commission, Report on Public Finances in EMU 2014 (rehearsing episodes of successful consolidations, concluding that revenue-based consolidations do not work nearly as well as expenditure-based consolidations, and recommending, on p 134, that 'cuts should concentrate on the more rigid and persistent components of government expenditure, namely compensation of employees and social benefits.') 
radical underestimation of the 'fiscal multiplier' ${ }^{43}$ The European Commission will have none of that, however. For them, the problem is simply that financial markets are 'short sighted', with sovereign debt spreads and borrowing costs frustrating any gains from fiscal consolidations. ${ }^{44}$ In other words, the financial markets just don't 'get it'.

\section{Gauweiler and how the market should behave}

With the OMT program, the ECB signaled its readiness to buy up massive quantities of government bonds of periphery countries from secondary markets. Not unreasonably, the compatibility of the program with the ECB's mandate and Article 123 TFEU was raised widely, and came to the Court of Justice via an extraordinarily didactic preliminary reference from the Bundesverfassungsgericht in Gauweiler. ${ }^{45}$

The first task at hand was to find a way to classify OMT as falling within the ECB's mandate as an instrument of 'monetary', rather than 'economic' policy. Since the Court had stated

${ }^{43}$ See O. Blanchard and D. Leigh, 'Growth Forecasts and Fiscal Multipliers', (2013) IMF Working Paper 13/1. On the development of policy in the IMF, see C. Ban, 'Austerity versus Stimulus? Understanding Fiscal Policy Change at the International Monetary Fund since the Great Recession', Governance (2014) 28 (2): 167-183.

${ }^{44}$ See for example European Commission, Report on Public Finances in EMU 2012, 115; J. Boussard, F. de Castro and M. Salto, 'Fiscal Multipliers and Debt Dynamics in Consolidations', European Commission Economic Papers 460/ 2012; K. Berti, F. de Castro and M. Salto, 'Effects of fiscal consolidation envisaged in the 2013 Stability and Convergence Programmes on public debt dynamics in EU Member States', European Commission Economic Papers 504/2013. The plot thickens in a theory that holds that the large presence of public creditors with real or perceived seniority pushes up yields in the market. See S. Steinkamp and F. Westerman, 'The role of creditor seniority in Europe's sovereign debt crisis', Economic Policy (2014) 29: 495-552. ${ }^{45}$ See generally for example D. Adamski, 'Economic Constitution of the Euro area after the Gauweiler preliminary ruling', Common Market L Rev (2015) 52: 1451-1490; M. Wilkinson, 'The Euro is Irreversible!...Or Is It?: On OMT, Austerity and the Threat of "Grexit"', German L J (2015) 16: 1049-1072; V. Borger, 'Outright Monetary Transactions and the stability mandate of the ECB: Gauweiler', Common Market L Rev (2016) 53: 139-196, and P. Craig and M. Markakis, 'Gauweiler and the legality of outright monetary transactions,' European L Rev (2016) 41: 4-24. 
categorically in Pringle that 'financial assistance to a member State clearly does not fall within monetary policy, ${ }^{46}$ the imperative was to cast the ECB's intervention- which rather obviously had as its immediate objective to lower spreads and rates and so to lower refinancing costs for indebted Member States- as something other than 'assistance.'

To this end, the Court had little choice but to take sides with the ECB against both the Bundesverfassungsgricht and the Bundesbank. It thus took over the ECB's theory of having to clear noise from the system: since the effectiveness of monetary policy depends on the transmission of 'impulses' sent out across the money market to the various sectors of the economy, the concept of 'monetary policy' has to include any measures designed to repair that transmission mechanism in case it is disrupted. ${ }^{47}$ The Court also accepted the ECB's analysis that the economic situation in the euro area was characterized by 'high volatility and extreme spreads', spreads that 'were not accounted for solely by macroeconomic differences between the States concerned but were caused, in part, by the demand for excessive risk premia for the bonds issued by certain Member States, such premia being intended to guard against the risk of a break-up of the euro area. ${ }^{48}$ The next step was, then, simply, to classify 'excessive' interest rates as noise:

It is undisputed that interest rates for the government bonds of a given State play a decisive role in the setting of interest rates applicable to the various economic actors in that State, in the value of the portfolios of financial institutions holding such bonds and the in the ability of such institutions to obtain liquidity. Therefore, eliminating or reducing the excessive risk premia demanded of the government bonds of a member State is likely to avoid the volatility and level of those premia from hindering the transmission of the effects of the ESCB's monetary policy decisions to the economy of that State and from jeopardizing the singleness of monetary policy. ${ }^{49}$

\footnotetext{
46 Pringle, para 57.

47 Gauweiler, para 50.

48 Ibid., para 72.

49 Ibid., para 78.
} 
This is not the kind of economic engineering that finds much favor in Frankfurt and Karlsruhe. Probably the most significant argument against the ECB's theory is the one the Court of Justice completely ignores. As the German constitutional court points out, it is hard to conceive of any debt crisis where the 'monetary policy transmission mechanism' is not disrupted:

A critical deterioration of the solvency of a state typically coincides with a corresponding deterioration of the solvency of the national banking sector (so-called bank-state nexus). As a result, in this situation, the lending practices of the banks tend to hardly reflect the reductions in the key interest rate anymore; the monetary policy transmission mechanism is disrupted. If purchases of government bonds were admissible every time the monetary policy transmission mechanism is disrupted, it would amount to granting the European Central Bank the power to remedy any deterioration of the credit rating of a euro area Member State through the purchase of that state's government bonds. ${ }^{50}$

Even if the argument here seems unaffected by the question of the rationality of spreads and rates, the more visible and notorious disagreement between the two Courts consisted largely of a rehearsal of the econometric debate about the role of 'fundamentals' in the spreads. The Bundesverfassungsgericht had no trouble working this seamlessly into an argument about the role of 'market discipline' in the incentive structure of EMU, and throwing Pringle back in the face of the Court of Justice:

According to the European Central Bank, these spreads are partly based on fear declared to be irrational - of investors of a reversibility of the euro. However, according to the convincing expertise of the Bundesbank, such interest rate spreads only reflect the skepticism of market participants that individual Member States will show sufficient budgetary discipline to stay permanently solvent. Pursuant to the design of the Treaty on the Functioning of the European Union, the existence of such spreads is entirely intended. As the Court of Justice of the European Union has pointed out in its Pringle decision, they are an expression of the independence of

\footnotetext{
${ }^{50}$ BVerfG, Order of the Second Senate of 14 January 2014, 2 BvR 2728/13, BVerfGE 134, 366,
} para 97. 
national budgets, which relies on market incentives and cannot be lowered by bond purchases by central banks without suspending this independence. ${ }^{51}$

The Bunderverfassungsgericht surely opens itself up to justified criticism embracing an theory that is demonstrably false: the convincing expertise of Paul de Grauwe and his collaborators does a fine job undermining the assertion that spreads are only a function of public debt ratios. ${ }^{52}$ But this criticism ignores the way the constitutional court later on develops a stance separate from the 'convincing expertise' of the Bundesbank that is rather more interesting. Where the court first references 'explanations' given by the Bundesbank according to which 'one cannot, in practice, divide interest rates into a rational and an irrational part', ${ }^{53}$ it subsequently dismisses the distinction entirely as not just 'impossible to operationalise', but as 'irrelevant' and 'meaningless':

Spreads always only result from the market participants' expectations and are, regardless of their rationality, essential for market-based pricing. To single out and neutralise supposedly identifiable individual causes would be tantamount to an arbitrary interference with market activity. ${ }^{54}$

The Bundesverfassungsgericht, in other words, has no difficulty at all in conceiving of markets as social and political institutions consisting of operators and participants with hopes, fears and interests. It may be 'market fundamentalist', but its faith and loyalty is to markets as they actually behave. What the Court of Justice does is altogether more insidious: this is market fundamentalism loyal not to actual market behavior, but to some mysterious equilibrium reached by hypothetical markets that we have never actually witnessed in real life, that we have no particularly compelling theoretical reason to believe could ever materialize, and that we have to accept on the force of our faith in the expertise

\footnotetext{
51 BVerfGE 134, 366, para 71.

52 See P. De Grauwe, Y. Ji and A. Steinbach, The EU debt crisis: testing and revisiting conventional legal doctrine, (2016) LSE 'Europe in Question' Discussion paper 108/2016.

53 BVerfGE 134, 366, para 71.

${ }^{54}$ Ibid., para 98. Emphasis added.
} 
of the ECB. ${ }^{55}$ By accepting the theory of 'excessive' interest rates, the Court also embraces the concept of 'right' and 'proper' interest rates that can be discerned and engineered by technicians. This is not just an academic exercise: this elusive equilibrium is the dividing line between admissible monetary policy and prohibited economic policy, and the exact measure of how much austerity is legally required of debtor states.

When the ESM buys up bonds on secondary markets, it is 'economic policy.' When the ECB does the same, and makes these purchases conditional on compliance with the ESM's 'macroeconomic adjustment' demands, it is 'monetary policy.' In this regard, the Court holds, it is the difference between the objectives of the respective operations which is decisive. ${ }^{56}$ By accepting the ECB's objective of 'repairing' a 'disrupted' monetary policy transmission mechanism, and by demanding that OMT cease 'as soon as these objectives have been achieved', ${ }^{57}$ the magical moment when 'the market' will be restored to its purified 'logic' is the precise boundary of the legality of the programme. ${ }^{58}$

That equilibrium is also the the measure of exactly the right amount of 'market discipline' Member States ought to be subjected to. Pulling the plug on OMT as soon as the noise has been cleared means

(i)that the Member States cannot, in determining their budgetary policy, rely on the certainty that the ESCB will at a future point purchase their government bonds on secondary markets and (ii) that the programme in question cannot be implemented in a way which would bring about a harmonization of the interest rates applied to the government bonds of the Member States of the euro area regardless of the differences arising from their macroeconomic or budgetary situation.

The adoption and implementation of such a program thus do not permit the Member States to adopt a budgetary policy which fails to take account $f$ the fact that

\footnotetext{
55 Gauweiler, para 75 ('nothing more can be required of the ESCB apart from that it use its economic expertise and the necessary technical means at its disposal to carry out that analysis with all care and accuracy.')

56 Ibid. para 64.

57 Ibid., para 82.

${ }^{58}$ Ibid., para 82 and para 112.
} 
they will be compelled, in the event of a deficit, to seek financing on the markets, or result in them being protected against the consequences which a change in their macroeconomic or budgetary situation may have in that regard..$^{59}$

Before that moment is reached, however, we still need conditionality and austerity, lest OMT would be perceived 'as an incentive to dispense with fiscal consolidation. ${ }^{60}$

More disastrously still, the Court demands- as it did in Pringle- that the ECB's interventionwhich has as its objective to return irrational markets to the 'logic of the market'- takes place according to the 'logic of the market.' And that means- as it did in Pringle- that the legality of the intervention depends on its being as ineffective as possible. This comes out clearly in the Court's treatment of Article 123 TFEU's prohibition of monetary financing. This outlaws purchases on primary markets, but not purchases on secondary markets. The Court, however, in view of the objective of 'encouraging' sound budgetary policies, will not allow the ECB to go on a buying spree that would have 'an effect equivalent to that of direct purchases of government bonds. ${ }^{61}$ That means, in turn, that the ECB will have to disrupt the functioning of the irrational market according to the logic of the irrational market. And thus 'safeguards' have to be built in to OMT: enough time should be left between issues on primary markets and purchases on secondary markets for 'normal' price formation to take place; there may not be any prior announcement of whether and how much the ECB plans to buy where, lest 'normal' price formation is corrupted; ;2 the ECB may not claim seniority creditor status lest OMT would affect 'normal' price formation. ${ }^{63}$ In one of the most startling passages of the judgment, the Court notes with apparent regret that 'it is true that, despite those safeguards, the ESCB's intervention remains capable of having...some influence on the functioning of the primary and secondary sovereign debt markets,' only to remember,

\footnotetext{
59 Ibid., paras 113-114.

60 Ibid., para 120.

61 Ibid., para 97.

62 Ibid., paras 104-107.

${ }^{63}$ Cryptically, ibid., para 126.
} 
almost as an afterthought, that such an effect is the very purpose of the OMT programme.

\section{Conclusion}

At the time of writing, the ECB has purchased, through its Public Sector Purchase Program, close to a trillion Euros' worth of central government bonds, almost a quarter of which from Germany. ${ }^{65}$ The only Eurozone country excluded from the extravaganza is Greece, whose 'credit quality' doesn't meet the Bank's exacting standards. It is inherent in 'the logic of the market' that credit is readily available and cheap for those who don't really need it, that it gets more expensive the more you need it, and that it slides out of reach altogether for those who cannot do without it. In theory, one can see how a well functioning sovereign debt market (if such a thing could ever exist) might exercise some discipline that could be useful to keep States from getting themselves into trouble. As a recipe to get States out of the trouble they didn't cause themselves, however, 'the logic of the market' is just punitive and cynical politics masquerading as inept economics. To freeze political substitutes for market discipline (ESM) and technocratic truth-seeking about the 'correct' price of debt (OMT) into law as the standard of permissible assistance and as the measure of austerity is rather worse than just bad law. This is how we live in Euroland.

${ }^{64}$ Ibid., para 108.

65 https://www.ecb.europa.eu/mopo/implement/omt/html/index.en.html 